\title{
The Meeting of a Saint and a Poet: W.B. Yeats and Purohit Swami
}

\author{
Dr. Sanjay Kumar Dutta \\ Asst. Prof of English \\ SG Women's College, \\ Rourkela, India
}

DOI: 10.53032/TCL.2021.6.1.20

\begin{abstract}
A literary artist seldom works in a vacuum, in isolation; rather, he draws materials of his art from the social, cultural, political and philosophical currents of his milieu, and eventually contributes his interpretation of these ideas to society. Yeats is not an exception; but his critical sensibility looked far towards Indian ideas. He found Indian ideas of art, philosophy, and religion inspiring and stimulating to such an extent that a vital part of career was engaged in assimilating as well as reproducing them through his own art. Though Yeats' critics and biographers have already noted the impact of Indian thought on his poetry, the present paper endeavors to show the interface between Yeats and Purohit Swami and how their friendship resulted in a mutual enrichment.
\end{abstract}

Keywords- Culture, Tradition, Indianness, Society, Religion

India and her literatures of wisdom have been a perennial source of inspiration to the world at large and have carved out an abiding place in the hearts of many western poets. Unlike others, Yeats' affinity with Indian thought and Indian outlook on life has somehow been closer than that of any comparable western poet who came under that spell at some time or the other, because of his long lasting friendship with three Indians at different stages of his career. His interest, as Wrenn points out, was not with the 'India of politicians or Historians or Travelers, but an India of pure romance which bears some subtle but obvious relation to the old Ireland' (9). Shri Purohit Swami was the last major figure in Yeats' romance with Indian thought that had begun 


\section{The Creative Launcher}

\section{An International, Open Access, Peer Reviewed, Refereed, E- Journal in English Editor-in-Chief-Dr Ram Avadh Prajapati}

with Mohini Chatterji and was carried on through Rabindranath Tagore. The spiritual quest of Yeats was intensified when he met that great Indian monk.

Though the intensity of Yeats' preoccupation with the Indian ideas varied from time to time depending upon his friendship with the three Indians, it was productive and valuable, both for Yeats and for India. There is no reason to believe that the last phase of Yeats' relationship with India is less important in comparison with the first and the second. For this belief is based, as Sanker Mokashi-Punekar in his "Shri Purohit Swami and W. B. Yeats" says, on the assumption that Yeats' relationship with Swami was more personal and philosophical than literary (27-28). But on the contrary, it can also be the case that the last phase is the most productive part of his relationship with India because of his collaboration with Swami for the translation of the Upanishads, which can be regarded as its culmination.

Yeats met Shri Purohit Swami, a Brahmin from Maharashtra who became an ascetic and took to Yogic life, at Sturge Moore's house in 1931, (Sankaran, 81). Immediately after this meeting, "Yeats' sentiments towards India were once again aroused" (Guha, 140).Their friendship lasted till the end of Yeats' life. Swami stayed in Europe for five years and produced five books, and with each of them Yeats' name was associated. For a long period of time both of them lived together.

Swami was asked by his master Shri Hamsa to go and 'interpret the esoteric phase of Indian life to the west' (An Indian Monk, 189). The esoteric phase of Indian life which Swami spoke was not new to Yeats, as he was familiar with it because of his acquaintance with Mohini Chatterji and the Theosophical society. But, Yeats confessed that 'the most eminent scholars left me credulous' (Preface, TTPU7). It was at this critical juncture in his search for a concrete meaning of Indian philosophy that he came across Swami. This presented him with the opportunity to communicate with a man who had not only read Indian philosophy but practiced it in his life, and who could explain, answer and remove doubts if any arose. Swami found in Yeats a guide and collaborator and the latter found in the former a friend and philosopher in whom were some, "readily discovered confirmation of some of his theories from this little known religious preacher from India” (Guha 126). 


\section{The Creative Launcher}

\section{An International, Open Access, Peer Reviewed, Refereed, E- Journal in English} Editor-in-Chief-Dr Ram Avadh Prajapati

Whatever Yeats heard from Swami, he related to the ideas that had already taken root in his mind because of his earlier acquaintances. Yeats' genuine interest was in getting Shri Purohit Swami's experiences recorded in his prose as well as in his poems. In a sense Yeats devoted much of the energies of his last years to the promotion of Swami's work. The interest in Swami's work was motivated by Yeats' search for the revelation of arcane mysteries which Yeats believed existed on a hidden plane. In fact, Yeats was far less concerned with the scholarly accuracy of Swami's work than with the spiritual truth they seemed to embody.

Five books were produced by Swami during his contact with Yeats and that his first work An Indian Monk began on Yeats' suggestion, because a few years later, in 1936 Swami wrote to Yeats "you asked me to write my tale; now it is my turn to ask you to complete your autobiography" (quoted in Sankaran 81). Yeats added an introduction to An Indian Monk. His enthusiasm in getting Swami's autobiography published was inspired by his hope to find a support in it that could give authenticity to spiritual ideas. It is because as Sankaran has observed, "the authenticity of spiritual experiences, Yeats thought could help other readers like him to evaluate how far the supernatural realms were attainable to man when alive" (82). Yeats needed someone's experiences for verification and the Swami's autobiography was helpful in this context. Yeats wrote in the introduction to An Indian Monk in 1932, "The book lies before me complete; it seems to me something I have waited for since I was seventeen years old.... I found all I wanted" (xviii). Swami's experiences were enough verification and proof for Yeats that supernatural or irrational experiences were real and as true as physical existence.

In the earlier years he came across only someone expounding Indian philosophy without having anything from his own life to cite to convince a hearer about the authenticity of the soul or rebirth, but in Swami, Yeats found real experience that proved to him the truth of such ideas. It is through Swami that Yeats was convinced that there was a world that was beyond the comprehension of reason. Another remarkable thing which Yeats noticed was that Swami did not belong to the school of Sankara for whom the world was an illusion. For Swami the world was "part of the "splendor and being"" (Introduction, An Indian Monk xx). Yeats believed in the reality of life, particularly at a time when having been challenged by death because of his recent 


\section{The Creative Launcher}

\section{An International, Open Access, Peer Reviewed, Refereed, E- Journal in English} Editor-in-Chief-Dr Ram Avadh Prajapati

illness he had clung to life more and more. This aspect of the Swami's philosophy might have had a special appeal for Yeats.

The next book of Swami, The Holy Mountain, which appeared two years later, was not an original work, rather an English translation of a Marathi book written by his Master, which describes his pilgrimage to mount Meru in Tibet and to Lake Mansarowar where he claimed, he had been initiated into the Giri Order of Sanyasinis. Once again Yeats contributed a long introduction to this work. He also wrote about the book in a letter to Mrs Shakespeare in 1934"I have just sent back final proofs of The Holy Mountain and have just read it all through. It seems to me one of those rare books that are fundamental. For generations of writers will refer to it as they will to An Indian Monk. Two such books will shift for those who move others the foundation of their thought but it will take years" (Introduction, The Holy Mountain 22-3).

In his introduction to The Holy Mountain Yeats describes the four states of the soul as described in the Mandukya Upanishad. Naturally he had learnt all this from the intellectual discourse of Purohit Swami. The introduction makes an interesting reading and also enlightens us about Yeats' knowledge of the Upanishads. Yeats writes: “....the waking state, corresponding to the letter 'A', where physical objects are present, the dreaming state corresponding to letter 'U', where mental objects are present, the state of dreamless sleep corresponding to the letter ' $\mathrm{M}$ ' where all seems darkness to the soul, because all there is, is lost in Brahma, Creator of mental and physical objects; the final state corresponding to the whole sacred word AUM, consciousness bound to no object, bliss bound to no aim, Turiya, pure personality" (Introduction, The Holy Mountain 22-3). According to Hindu belief attaining the fourth state must be the goal of a monk. Purohit Swami claimed that his master Shri Hamsa had attained the fourth state whereas he himself had reached only up to the third state namely that ofSushupti.

In 1935 Purohit Swami published translation of The Geeta and dedicated it to Yeats with the words, "accept this Geeta, the Upanishads in essence, a humble offering on your seventieth birthday" (The Geeta 9).The fourth book was the English translation of some important Upanishads. It was published in 1937 as The Ten Principal Upanishads. The book bears the 


\section{The Creative Launcher}

\section{An International, Open Access, Peer Reviewed, Refereed, E- Journal in English Editor-in-Chief-Dr Ram Avadh Prajapati}

names of both Purohit Swami and W.B. Yeats as authors. Yeats also wrote a short preface to the book. In his preface Yeats wrote:

"Shree Purohit Swami and I offer to some young man seeking like Shakespeare, Dante, Milton, vast sentiments and generalizations, the oldest philosophical compositions of the world... Whatever the date when those forest sages began everything; no fundamental problem of philosophy, nothing that has disturbed the schools to controversy, escaped their notice" (Yeats' preface, TTPU 10).

Yeats' preface to The Ten Principal Upanishads also informs us about his aim in translating the Sanskrit texts into English. From what he says in the preface, it surfaces that he translated The Upanishads to understand them to clarify various difficult concepts and in his own words 'to confound something in myself'. By the time the translation was completed Yeats had clearly understood the message given in The Upanishads that the individual self was the Supreme Self. In the preface Yeats clearly mentioned it. He said: "Continental investigators, who reject the spiritism of Lodge and Crookes, but accept their phenomena, postulate an individual self possessed of such power and knowledge that they seem at every moment about to identify it with that Self without limitation and sorrow, containing and contained by all, and to seek there not only the living but the dead." (Yeats' preface, TTPU 9).

Purohit Swami's last book, Aphorisms of Yoga, which is a translation of Patanjali's Yoga Sutra, was published in 1938 and Yeats had to provide an introduction. In Aphorisms of Yoga. Yeats found the synthesis of Western and Eastern thoughts. In his introduction Yeats tells us about his understanding of Yoga and he also compares the thoughts and ideas of Yoga with those of Swdenborg and Boehme. Yeats wrote: "In the seventeenth century conscious Samadhi reappeared in the 'waking trance' of Boehme ... and in the eighteenth, much contaminated by belief in the literal inspiration of Scripture, in the vision of Swdenborg. Possibly I should deny to the visions of Swedenborg... the character of conscious Samadhi...But we may, I think, concede to Swdenborg an impure Samdadhi" (Yeats' introduction, Aphorisms of Yoga 19-20).

Yeats found support for his own 'system' from The Upanishads and Hindu lore through his close association with Purohit Swami. It seems probable that of all the systems Yeats 


\section{The Creative Launcher}

\section{An International, Open Access, Peer Reviewed, Refereed, E- Journal in English Editor-in-Chief-Dr Ram Avadh Prajapati}

investigated to find affinity or authority for his own, none was found suitable and satisfying to him as that of the Hindus. Yeats' own book A Vision (1937) was also rewritten during the years when he was in contact with Purohit Swami. Yeats' awareness of the supernatural experiences of Shri Purohit Swami and his guru, Bhagavan Shri Hamsa, and his close reading of the Upanishads played a major role in solving the problem that he handled in "A Dialogue of Self and Soul" and "Vacillation".

Yeats' predilection for the spiritual philosophy of the Upanishads can also be seen in his poem 'A Prayer for my Son', where he says his son is but an incarnation of God. The poems in Supernatural Songs and the poem 'Meru' and also the play The Herne's Egg are heavily influenced by the spiritual teachings of the Swami. In fact, Yeats wrote about The Herne's Egg that it is suffused with Hindu philosophy: "Shri Purohit Swami is with me and the play is his philosophy in a fable, or mine confirmed by him”.

The five essays of Yeats demonstrate that it is his best contribution to the western understanding of India and because of this friendship Yeats could introduce four Indian books to the western world as well as to the English speaking Indians who might not have thought much about the relevance of the ancient Indian writings. It is now evident that Yeats' friendship with Swami was useful for both of them in terms of sharing their scholarship, and particularly, Yeats' understanding of some difficult concepts of Indian Philosophy. Yeats could after that authoritatively talks about the Upanishads, the Gita. Most importantly, Yeats found in the presence of the Swami a peace that he pined for but did not find anywhere else. He wrote: "the very fact that I am gaining with a man whose mind I touch on only one point, means peace". But more than that, we can say Yeats was a good friend of Swami. In fact, for almost all of his achievements in Europe, Shri Purohit Swami is indebted to Yeats. Equally, on the other side, Yeats felt spontaneously sympathetic towards this saffron-clad Yogi from India, who had no organizations to support his missionary program or to help him in his plans to publish his writings. The help that Yeats extended to Swami in his missionary work is a glorious chapter in Yeats' relation with India. For four years they were closely associated, until in 1936 Swami returned to India. 


\section{The Creative Launcher}

\section{An International, Open Access, Peer Reviewed, Refereed, E- Journal in English} Editor-in-Chief-Dr Ram Avadh Prajapati

\section{References}

Guha, Naresh. W.B. Yeats: An Indian Approach. Jadavpur University Press, 1968.

Mokashi-Punekar, Shankar. "W.B. Yeats and Sri Purohit Swami”. In The Image of India in Western Creative Writing. ed. M.K. Naik et al. Dharwar: Karnata University; Macmillan, 1972.

Sankaran, Ravindran. W. B. Yeats and Indian Tradition. Konark, 1990. Print

Swami, Shri Purohit.ed. Bhagavat Gita. Faber and Faber,1935.

Wrenn, C.L. W.B. Yeats: A Literary Study. Thomas Murby \& Co. 1920

Yeats, W.B. Preface. The Ten Principal Upanishads. Trans. Shri Purohit Swami and W.B.Yeats. Macmillan, 1937.

---. Introduction. An Indian Monk: His Life and Adventures. By Shri Purohit Swami. Macmillan, 1932.

---. Introduction. The Holy Mountain. By Bhagavan Shri Hamsa. Trans. Shri Purohit Swami. London: Faber and Faber, 1934.

---. Introduction. Aphorisms of Yoga. By Bhagavan Shri Patanjali. Trans. Shri Purohit Swami and W. B. Yeats. London: Faber and Faber, 1938. 